\title{
Changes in salt-marsh carabid assemblages after an invasion by the native grass Elymus athericus (Link) Kerguélen
}

\author{
Anita Georges', Philippe Fouillet², Julien Pétillon ${ }^{2,3}$ \\ I U.M.R. 6553 - "Ecosystèmes, Biodiversité, Evolution", Université de Rennes 1, 263 Avenue du Gal Leclerc, \\ CS74205, 35042 Rennes Cedex, France 2 U.R.U. 420 - "Biodiversité fonctionnelle et Gestion des territoires", \\ Université de Rennes 1, 263 Avenue du Général Leclerc, CS 74205, 35042 Rennes Cedex, France 3 Evolutionary \\ Ecology Group, University of Antwerp, Groenenborgerlaan 171, 2020 Antwerpen, Belgium \\ Corresponding author:Julien Pétillon (julien.petillon@univ-rennes1.fr)
}

Academic editor: J. Noordijk | Received 1 December 2009 | Accepted 1 April 2010 | Published 20 May 2011

Citation: Georges A, Fouillet P, Pétillon J (2011) Changes in salt-marsh carabid assemblages after an invasion by the native grass Elymus athericus (Link) Kerguélen. In: Kotze DJ, Assmann T, Noordijk J, Turin H, Vermeulen R (Eds) Carabid Beetles as Bioindicators: Biogeographical, Ecological and Environmental Studies. ZooKeys 100: 407-419. doi: $10.3897 /$ zookeys.100.1537

\begin{abstract}
As a result of an invasion by the native grass Elymus athericus (Link) Kerguélen (Poaceae) in the last 10 years, a major change in vegetation cover has occurred in salt marshes of the Mont Saint-Michel bay, Western France. The impact of such an invasion on carabid assemblages, a dominant group of terrestrial arthropods in these habitats and containing several stenotopic species, is investigated here. In our study site, carabid data are available from 1983 and 1984, allowing a comparison of species distribution ranges in salt marshes before (1983-1984) and after (2002) the E. athericus invasion. A total of 16,867 adults belonging to 40 species were caught. By considering the presence-absence of species shared between studies, we show that the invasion by E. athericus promoted the progression of non-coastal species (mainly Pterostichus s.l. spp.). This did however not interfere with resident species distributions, finally resulting in higher carabid species richness in the entire area. The species composition and abundances of carabid assemblages were also compared between natural and invaded stations in 2002. The main result is that abundances of some halophilic species decreased in one invaded plot (in case of Pogonus chalceus (Marsham 1802)) whereas the opposite pattern was observed for other species (e.g., Bembidion minimum (Fabricius 1792)). Invaded habitats were characterized by lower percentages of halophilic species and higher total species richness.
\end{abstract}

\section{Keywords}

Coleoptera, Carabidae, native invasive species, salt marsh, ecological indicators

Copyright A. Georges, P. Fouillet, J. Pétillon. This is an open access article distributed under the terms of the Creative Commons Attribution License, which permits unrestricted use, distribution, and reproduction in any medium, provided the original author and source are credited. 


\section{Introduction}

Intertidal salt marshes are ecosystems located between land and sea, undergoing periodical flooding during tides, occurring around twice a month in West-Europe. This creates some special habitat conditions, and marsh plants and animals often have special adaptations to cope with these. Salt-marsh arthropods are able to withstand floods and salinity by physiological, behavioural or morphological adaptations (e.g., Foster \& Treherne 1976, Irmler et al. 2002, Pétillon et al. 2009). Salt marshes are among the rarest habitats in the world, covering less than $0.01 \%$ of the Earth's surface (Desender \& Maelfait 1999, Lefeuvre et al. 2003). In Europe, their surface strongly declined during the last decades, reinforcing the conservation interest in their original flora and fauna (Bakker et al. 2002). There is thus an urgent need to study human impacts that can either threaten (by e.g., over-grazing or habitat destruction), or enhance (by appropriate management) halophilic species in salt marshes (Goeldner-Gianella 1999, Adam 2002).

More recently, salt marshes have been invaded in many West-European sites by the nitrophilous grass Elymus athericus (Poaceae) (Valéry et al. 2004), probably due to increases in soil nitrogen (via the accumulation of nitrogenous compounds in the plant: Leport et al. 2006) and/or to the abandonment of agricultural practises (e.g., Esselink et al. 2000). Although Elymus athericus is a native species in Europe (Bockelmann \& Neuhaus 1999) - usually growing in the upper parts of salt marshes - it can form dense, mono-specific stands, which corresponds to an invasion. This is likely to modify biodiversity and consequently ecosystem proprieties and functions as well as the conservation value of invaded areas (Valéry et al. 2009). Invaded areas mainly differ from natural habitats (usually dominated by Atriplex portulacoides, Chenopodiaceae, in ungrazed middle marshes) by their enhanced litter layer and by their higher plant cover.

According to McGeoch (1998), a taxonomic group is an ecological indicator if it responds to environmental changes, stressful or not. In this study, we focussed on ground beetles (Coleoptera, Carabidae) as they are known to react quickly and strongly to changes in micro-habitat conditions. This group is thus frequently used as an indicator of human disturbances or management practices (e.g., Luff et al. 1992, Georges 1994, Sunderland \& Lövei 1996, Rainio \& Niemelä 2003). The assessment of human impact was conducted by comparing two conservation criteria, i.e., abundance of halophilic species and species richness, between natural and invaded stations. Species richness is widely used as a conservation target (e.g., Noss 1990, Bonn \& Gaston 2005). The use of stenotopic species is also recommended in studying the impact of human activities on arthropod communities (Samways 1993, New 1995, Dufrêne \& Legendre 1997). In this study, the target species were halophilic species, defined by their preference or exclusive presence in salt-marsh habitats (Kamer et al. 2008), which can be assessed using distribution maps (in our study, relevant atlases are Luff 1998 and Turin 2000). Two approaches were used for assessing changes in natural salt marshes compared to invaded ones: (i) a diachronic (before vs. after the invasion) comparison 
of species distribution along a land-sea gradient and (ii) a synchronic comparison of species assemblages between invaded and natural habitats.

\section{Methods}

\section{Study site and sampling design}

The Mont Saint-Michel bay (NW France) is an extensive littoral zone $\left(500 \mathrm{~km}^{2}\right)$ located between the regions Brittany and Normandy (48 $\left.40^{\prime} \mathrm{N}, 1^{\circ} 40^{\prime} \mathrm{W}\right)$. Two sites have been studied in salt marshes: "la Ferme Foucault", on the western part of the Mont St.-Michel (coded F; $48^{\circ} 37^{\prime} \mathrm{N}, 1^{\circ} 32^{\prime} \mathrm{W}$ ) and "la Rive” on the eastern part of the Mont St.-Michel (coded R; 48³7’N, $1^{\circ} 29^{\prime} \mathrm{W}$ ) (Fig. 1).

For the diachronic approach, ground beetle populations were compared at seven stations (A to $G$ ) located along the same land-sea transect at the "Ferme Foucault" site between 1983-1984 and 2002. During the study of 1983-1984, Elymus athericus was restricted in this salt marsh to the dyke (station A) and to the upper marsh (station B), but absent from stations C-G. Invasion by Elymus athericus modified the plant cover of the sampling stations between 1984 and 2002. The middle marsh and lower marsh stations (station C till F), dominated in 1984 by Atriplex portulacoides (Chenopodiaceae), were dominated by E. athericus in 2002.

Secondly, natural (dominated by Atriplex portulacoides), and invaded (dominated by Elymus athericus) stations were studied at different marsh levels in the synchronic approach. Comparisons of paired stations (natural and invaded - coded N and I, respectively) were spatially replicated three times for avoiding pseudo-replication (Hulbert 1984). Paired stations were located at the same distance from the dyke because of the existence of a salinity gradient influencing both species richness and abundance (Pétillon et al. 2004): stations 1 (350m), stations 2 (800-900m; both couples of stations at the "Ferme Foucault" site) and stations 3 (1000 meters from the dyke; "La Rive" site). Because of the clonal progression of the invasive species, all Elymus populations (stations I1, I2 and I3) formed a uniform and continuous plant cover. The natural areas sampled were either patch-like formations (in case of stations $\mathrm{N} 1$ and N2) or strip-like formations (station N3). Mean salinities did not significantly differ between invaded and natural stations at each salt marsh level (Pétillon et al. 2005) and elevations were similar between compared stations (J.C. Castel \& J. Huet, 1999, unpublished data). More details on the sampling stations can be found in Fouillet (1986) and Pétillon (2005).

\section{Sampling techniques and species identification}

For both the synchronic and diachronic approaches, ground beetles were sampled with pitfall traps, consisting of polypropylene cups $(10 \mathrm{~cm}$ diameter, $17 \mathrm{~cm}$ deep) with 


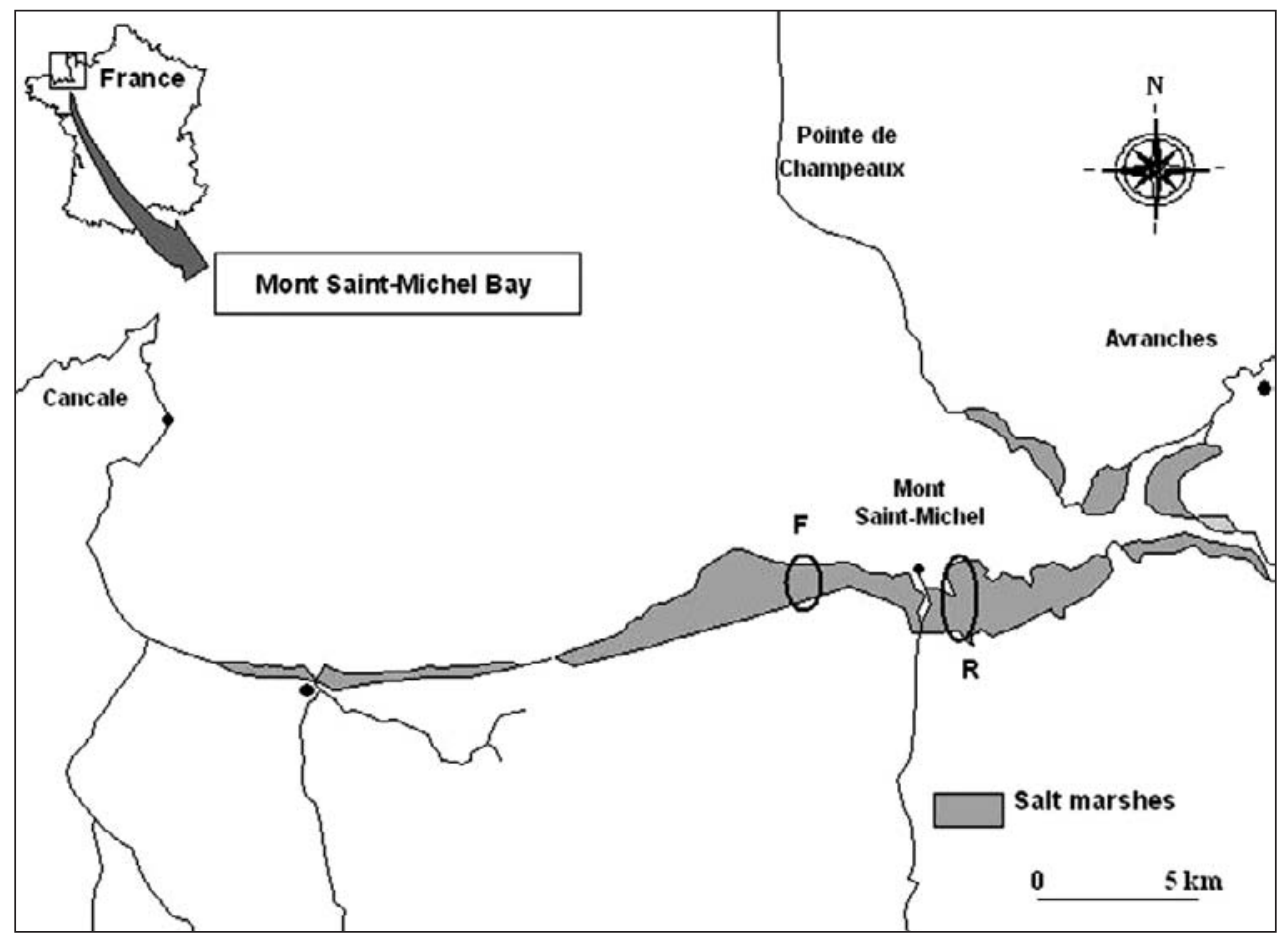

Figure I. Location of the study sites (Mont St-Michel Bay, France). Codes: F 'Ferme Foucault' R 'la Rive'.

ethylene-glycol as preservative. Traps were covered with a raised wooden roof to keep out rain. They were emptied weekly when tides permitted (i.e., about three weeks per month). Pitfall traps were grouped by four and spaced $10 \mathrm{~m}$ apart, this being considered to be the minimum distance for avoiding interference between traps (Topping $\&$ Sunderland 1992). Before the Elymus invasion, Fouillet (1986) sampled the transect with one trap per station from May to September in 1983 and 1984, for a total of 16 five-day samples. In 2002, four traps were installed at each station in both study sites, from April to November 2002. Sampling time was comparable between both periods (90 days in 1983-1984 and 96 days in 2002). Because of the differences in sampling efforts, we only compared the two studies on the basis of species presence / absence (i.e., distribution range along the land-sea transect).

Ground beetles were preserved in 70\% ethanol and identified using Jeannel (1942) and Trautner \& Geigenmüller (1987). Nomenclature follows Lindroth (1992) as far as possible, and Fauna Europaea otherwise (http://www.faunaeur.org/).

\section{Data analyses}

Statistics on the abundances of halophilic species were performed only for species represented by at least 10 individuals in couples of stations. Catches in pitfall traps were 
related to trapping duration and pitfall trap perimeter, which calculates an "activity trappability density" (number of individuals per day and per meter - Sunderland et al. 1995). Mean species richness and mean abundances were compared using a two-way mixed model (habitat $\times$ station) with habitat type as fixed factor, station (1,2 and 3) and interaction habitat*station as random factors. In case of non-significant interaction between habitat type and station, the interaction was removed from the model and a new model was performed for detecting significant effects of habitat type and/ or station. In case of significant interaction between habitat type and station, parameters were analysed station by station (one-way ANOVA). Statistical analyses were performed using the Statistica-7 software.

\section{Results}

\section{Diachronic approach}

A total of 24 species (represented by 7,774 individuals) and 35 species (represented by 8,588 individuals) were caught in 1983-1984 and in 2002, respectively. Five species were exclusive to the first sampling period and 16 to the second one. All the species that were only recorded in 1983-1984 were caught in very low numbers (max. 2 individuals), four species on the dyke (Clivina colaris, Dromius linearis, Harpalus rufibarbis and $H$. rufipes) and only one in the salt marsh (Dyschirius chalceus). As the sampling effort was quite different between 1983-1984 and 2002 (see Material and Methods), it cannot be concluded that the 'appearance' of species between the two studies can be related to the invasion by Elymus athericus. The comparison in distribution was thus restricted to the 19 shared species (Table 1).

In terms of distribution ranges, two groups of carabids were distinguished: species with constant distribution range in the salt marsh or on the dyke and species with an increased distribution range between 1983-1984 and 2002. Eight species were caught on the dyke in 1983-1984 and in 2002, and seemed not to have progressed with Elymus athericus in the salt marsh (Amara equestris, Anisodactylus binotatus, Bembidion tetracolum, Harpalus anxius, Leistus fulvibarbis, Nebria brevicollis, Pterostichus melanarius and P. niger: Table 1). Eight other species had a similar habitat range in the salt marsh, extending from the upper to lower marsh or from the dyke to the lower marsh (halophilic species: bold in Table 1), plus two high-marsh living species (Badister bipustulatus and Pterostichus vernalis), one low-marsh living species (Dyschirius salinus) and one species with a discontinuous range along the land-sea transect (Loricera pilicornis). Only three species showed an extension of their distribution in the salt marsh, both to the upper and lower marsh (Bembidion iricolor, B. lampros and Pterostichus cupreus).

The Elymus athericus invasion led to a decrease in the percentage of halophilic species in invaded salt marshes (Fig. 2). 
Table I. Comparison of total catches (number of individuals) between 1983-1984 and 2002 along a land-sea transect (Foucault site; bold: halophilic species). The letters $\mathbf{A - G}$ indicate different sampling stations. In 1983-1984, only stations A-B had a dominant Elymus athericus cover; in 2002 at all stations Elymus athericus was present (dominant cover for stations $\mathbf{A}$ to $\mathbf{F}$ ).

\begin{tabular}{|c|c|c|c|c|c|c|c|c|c|}
\hline & Period & $\mathbf{A}$ & $\mathbf{B}$ & $\mathrm{C}$ & $\mathbf{D}$ & $\mathbf{E}$ & $\mathbf{F}$ & G & Total \\
\hline \multicolumn{10}{|l|}{ SHARED SPECIES } \\
\hline \multirow{2}{*}{$\begin{array}{l}\text { Amara equestris } \\
\text { (Duftschmid 1812) }\end{array}$} & 1983-84 & 1 & & & & & & & 1 \\
\hline & 2002 & 1 & & & & & & & 1 \\
\hline \multirow{2}{*}{$\begin{array}{l}\text { Anisodactylus binotatus } \\
\text { (Fabricius 1787) }\end{array}$} & $1983-84$ & 3 & & & & & & & 3 \\
\hline & 2002 & 6 & & & & & & & 6 \\
\hline \multirow{2}{*}{$\begin{array}{l}\text { Badister bipustulatus } \\
\text { (Fabricius 1792) }\end{array}$} & 1983-84 & & 1 & & & & & & 1 \\
\hline & 2002 & 2 & 2 & & & & & & 4 \\
\hline \multirow{2}{*}{$\begin{array}{l}\text { Bembidion iricolor Bedel } \\
1879\end{array}$} & $1983-84$ & 2 & & 2 & 2 & & & & 6 \\
\hline & 2002 & 5 & 98 & 89 & 21 & 1 & 4 & & 218 \\
\hline \multirow{2}{*}{$\begin{array}{l}\text { Bembidion lampros } \\
\text { (Herbst 1784) }\end{array}$} & $1983-84$ & 1 & & 2 & & & & & 3 \\
\hline & 2002 & 1 & 12 & 18 & 3 & 5 & 4 & 1 & 44 \\
\hline \multirow{2}{*}{$\begin{array}{l}\text { Bembidion minimum } \\
\text { (Fabricius 1792) }\end{array}$} & $1983-84$ & 4 & 1 & 40 & 52 & 10 & 2 & & 109 \\
\hline & 2002 & 1 & 31 & 13 & 5 & 80 & 96 & 3 & 229 \\
\hline \multirow{2}{*}{$\begin{array}{l}\text { Bembidion normanum } \\
\text { Dejean } 1831\end{array}$} & $1983-84$ & 1 & & 24 & 39 & 244 & 149 & 53 & 510 \\
\hline & 2002 & 2 & 6 & 8 & 13 & 212 & 131 & 24 & 396 \\
\hline \multirow{2}{*}{$\begin{array}{l}\text { Bembidion tetracolum (Say } \\
1823 \text { ) }\end{array}$} & 1983-84 & 1 & & & & & & & 1 \\
\hline & 2002 & 1 & & & & & & & 1 \\
\hline \multirow{2}{*}{$\begin{array}{l}\text { Dicheirotrichus gustavii } \\
\text { Crotch } 1871\end{array}$} & 1983-84 & 2 & & 11 & 83 & 2121 & 2622 & 393 & 5232 \\
\hline & 2002 & 2 & 8 & 2 & 3 & 136 & 237 & 156 & 544 \\
\hline \multirow{2}{*}{$\begin{array}{l}\text { Dyschirius salinus } \\
\text { Schaum } 1843\end{array}$} & 1983-84 & & & & & & 1 & 1 & 2 \\
\hline & 2002 & & & & & & & 5 & 5 \\
\hline \multirow{2}{*}{$\begin{array}{l}\text { Harpalus anxius } \\
\text { (Duftschmid 1812) }\end{array}$} & 1983-84 & 2 & & & & & & & 2 \\
\hline & 2002 & 1 & & & & & & & 1 \\
\hline \multirow{2}{*}{$\begin{array}{l}\text { Leistus fulvibarbis Dejean } \\
1826\end{array}$} & 1983-84 & 3 & & & & & & & 3 \\
\hline & 2002 & 1 & & & & & & & 1 \\
\hline \multirow{2}{*}{$\begin{array}{l}\text { Loricera pilicornis } \\
\text { (Fabricius 1775) }\end{array}$} & 1983-84 & & & & 1 & & & & 1 \\
\hline & 2002 & & & & & 1 & & 1 & 2 \\
\hline \multirow{2}{*}{$\begin{array}{l}\text { Nebria brevicollis } \\
\text { (Fabricius 1792) }\end{array}$} & 1983-84 & 3 & & & & & & & 3 \\
\hline & 2002 & 1 & & & & & & & 1 \\
\hline \multirow{2}{*}{$\begin{array}{l}\text { Pogonus chalceus } \\
\text { (Marsham 1802) }\end{array}$} & 1983-84 & 8 & 4 & 65 & 42 & 678 & 617 & 436 & 1850 \\
\hline & 2002 & 13 & 100 & 193 & 126 & 1628 & 1290 & 2243 & 5593 \\
\hline \multirow{2}{*}{$\begin{array}{l}\text { Pterostichus cupreus } \\
\text { (Linnaeus 1758) }\end{array}$} & 1983-84 & 3 & & 5 & & & & & 8 \\
\hline & 2002 & 7 & 41 & 9 & & & 2 & & 59 \\
\hline \multirow{2}{*}{$\begin{array}{l}\text { Pterostichus niger (Schaller } \\
1783 \text { ) }\end{array}$} & 1983-84 & 24 & & & & & & & 24 \\
\hline & 2002 & 1 & & & & & & & 1 \\
\hline \multirow{2}{*}{$\begin{array}{l}\text { Pterostichus vernalis } \\
\text { (Panzer 1795) }\end{array}$} & 1983-84 & 4 & & & & & & & 4 \\
\hline & 2002 & 2 & 1 & & & & & & 3 \\
\hline
\end{tabular}




\begin{tabular}{l|c|c|c|c|c|c|c|c|c}
\hline & Period & A & B & C & D & E & F & G & Total \\
\hline $\begin{array}{l}\text { Pterostichus melanarius } \\
\text { (Illiger 1798) }\end{array}$ & $1983-84$ & 4 & & & & & & & 4 \\
\cline { 2 - 10 } & 2002 & 12 & & & & & & & 12 \\
\hline
\end{tabular}

\section{SPECIES NOT RECOLLECTED IN 2002}

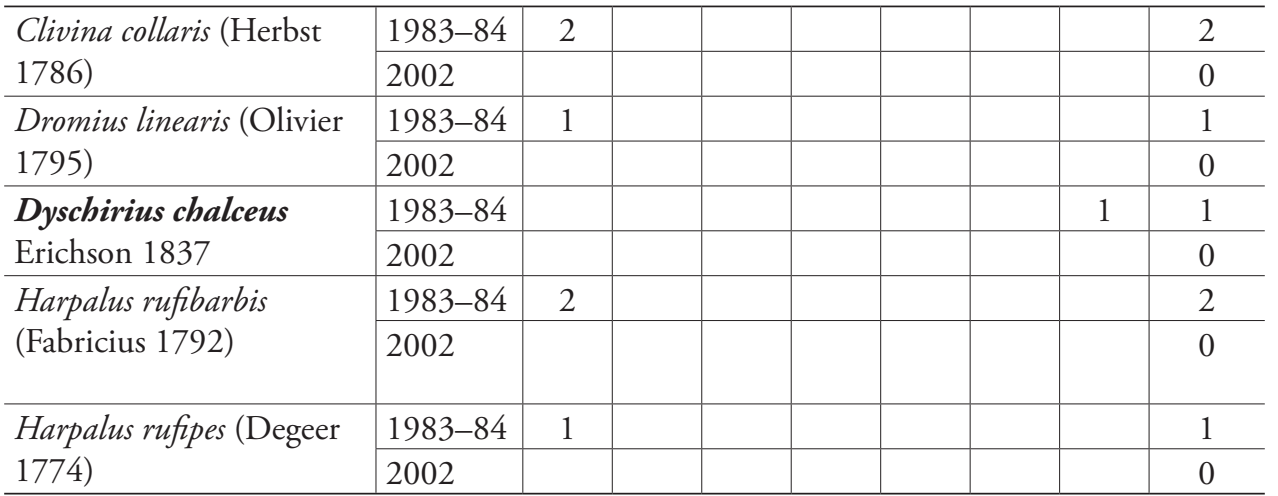

NEW SPECIES FOUND IN 2002

\begin{tabular}{|c|c|c|c|c|c|c|c|c|c|}
\hline \multirow{2}{*}{$\begin{array}{l}\text { Anchomenus dorsalis } \\
\text { (Pontoppidan 1763) }\end{array}$} & 1983-84 & & & & & & & & 0 \\
\hline & 2002 & 1 & & & & & & & 1 \\
\hline \multirow{2}{*}{$\begin{array}{l}\text { Agonum muelleri (Herbst } \\
1784 \text { ) }\end{array}$} & $1983-84$ & & & & & & & & 0 \\
\hline & 2002 & & & 5 & 1 & & & & 6 \\
\hline \multirow{2}{*}{$\begin{array}{l}\text { Amara lunicollis Schiödte } \\
1837\end{array}$} & $1983-84$ & & & & & & & & 0 \\
\hline & 2002 & 3 & & & & & & & 3 \\
\hline \multirow{2}{*}{$\begin{array}{l}\text { Amara plebeja (Gyllenhal } \\
1810 \text { ) }\end{array}$} & $1983-84$ & & & & & & & & 0 \\
\hline & 2002 & & 2 & & & & & 1 & 3 \\
\hline \multirow{2}{*}{$\begin{array}{l}\text { Amara tibialis (Paykull } \\
1798 \text { ) }\end{array}$} & $1983-84$ & & & & & & & & 0 \\
\hline & 2002 & 2 & & & & & & & 2 \\
\hline \multirow{2}{*}{$\begin{array}{l}\text { Anisodactylus poeciloides } \\
\text { (Stephens 1828) }\end{array}$} & $1983-84$ & & & & & & & & 0 \\
\hline & 2002 & & & 2 & & & & & 2 \\
\hline \multirow{2}{*}{$\begin{array}{l}\text { Bembidion obtusum } \\
\text { Serville } 1821\end{array}$} & 1983-84 & & & & & & & & 0 \\
\hline & 2002 & 10 & 16 & 1 & & & & & 27 \\
\hline \multirow{2}{*}{$\begin{array}{l}\text { Calathus mollis (Marsham } \\
1802 \text { ) }\end{array}$} & 1983-84 & & & & & & & & 0 \\
\hline & 2002 & & 1 & & & & & & 1 \\
\hline \multirow{2}{*}{$\begin{array}{l}\text { Clivina fossor (Linnaeus } \\
1758 \text { ) }\end{array}$} & $1983-84$ & & & & & & & & 0 \\
\hline & 2002 & & & & & & & 1 & 1 \\
\hline \multirow{2}{*}{$\begin{array}{l}\text { Dicheirotrichus } \\
\text { obsoletus (Dejean 1829) }\end{array}$} & 1983-84 & & & & & & & & 0 \\
\hline & 2002 & & 2 & 12 & 5 & 478 & 572 & 301 & 1370 \\
\hline \multirow{2}{*}{$\begin{array}{l}\text { Harpalus distinguendus } \\
\text { (Duftschmid 1812) }\end{array}$} & 1983-84 & & & & & & & & 0 \\
\hline & 2002 & 1 & & 2 & & & & & 3 \\
\hline \multirow{2}{*}{$\begin{array}{l}\text { Harpalus melancholichus } \\
\text { Dejean } 1829\end{array}$} & 1983-84 & & & & & & & & 0 \\
\hline & 2002 & 1 & & & & & & & 1 \\
\hline \multirow{2}{*}{$\begin{array}{l}\text { Microlestes minutulus } \\
\text { (Goeze 1777) }\end{array}$} & $1983-84$ & & & & & & & & 0 \\
\hline & 2002 & 2 & & & & & & & 2 \\
\hline
\end{tabular}




\begin{tabular}{l|l|c|c|c|c|c|c|c|c}
\hline & Period & A & B & C & D & E & F & G & Total \\
\hline $\begin{array}{l}\text { Pogonus littoralis } \\
\text { (Duftschmid 1812) }\end{array}$ & $1983-84$ & & & & & & & & 0 \\
\hline & 2002 & 1 & 13 & & 1 & & & & 15 \\
\hline $\begin{array}{l}\text { Pterostichus versicolor } \\
\text { (Sturm 1824) }\end{array}$ & $1983-84$ & & & & & & & & 0 \\
\hline $\begin{array}{l}\text { Tachys scutellaris } \\
\text { Stephens 1828 }\end{array}$ & 2002 & 4 & 14 & 2 & & & & & 20 \\
\hline \begin{tabular}{l} 
Total \\
\hline
\end{tabular} & 2002 & & 10 & & & & & & 10 \\
\hline
\end{tabular}

\section{Synchronic approach}

A total of 505 individuals belonging to 17 species were sampled in the three pairs of natural and invaded stations. The synchronous comparison of natural and invaded habitats revealed the existence of eight shared species. Two species were exclusive to natural habitats (Pogonus littoralis and P. luridipennis) and six to invaded habitats (Anisodactylus poeciloides, Bembidion obtusum, Harpalus anxius, H. distinguendus, Pterostichus cupreus and $P$. versicolor). Total species richness was higher in invaded habitats than in the natural ones (Table 2). Significant interactions between habitat type and station were found for species richness and two species Pogonus chalceus and Dicheirotrichus gustavii. Mean species richness was significantly higher in an invaded station compared to its adjacent natural one (one-way Anova, F-ratio=22.04, p=0.003, d.f.=7). More P. chalceus were caught at a natural station than at the paired invaded one (one-way Anova, F-ratio=14.68, $\mathrm{p}=0.009$, d.f.=7). D. gustavii was significantly higher in an invaded station compared to the natural one (one-way Anova, F-ratio=6.89, $\mathrm{p}=0.039$, d.f.=7) and the opposite pattern was found in another couple of stations (one-way Anova, F-ratio=11.94, p=0.014, d.f.=7). Bembidion minimum was significantly higher in invaded habitats compared to natural ones (Factorial Anova, F-ratio=5.91, $\mathrm{p}=0.025$, d.f.=20). No difference between habitat types was found for Dicheirotrichus obsoletus and Bembidion normanum (Table 2).

\section{Discussion}

By comparing data from 1983-1984 to 2002, we could show that only three species have extended their distribution range with the Elymus invasion, despite the existence of several dyke-inhabiting species (eight continental species with constant distribution). This result is opposite to those obtained for spiders in the same study site, with many range-expanding species (Pétillon et al. 2005). This pattern can also be related to the high percentage of halophilic carabid species found in salt marshes, much higher than for spiders (Pétillon et al. 2008). Assemblages of ground beetles in salt marshes proportionally contain more specific, halophilic species, and continental species are conversely unlikely to colonize this habitat. Meijer (1980) also noted that spiders were less sensitive to variations in soil salinity than ground beetles. Higher percentages of 


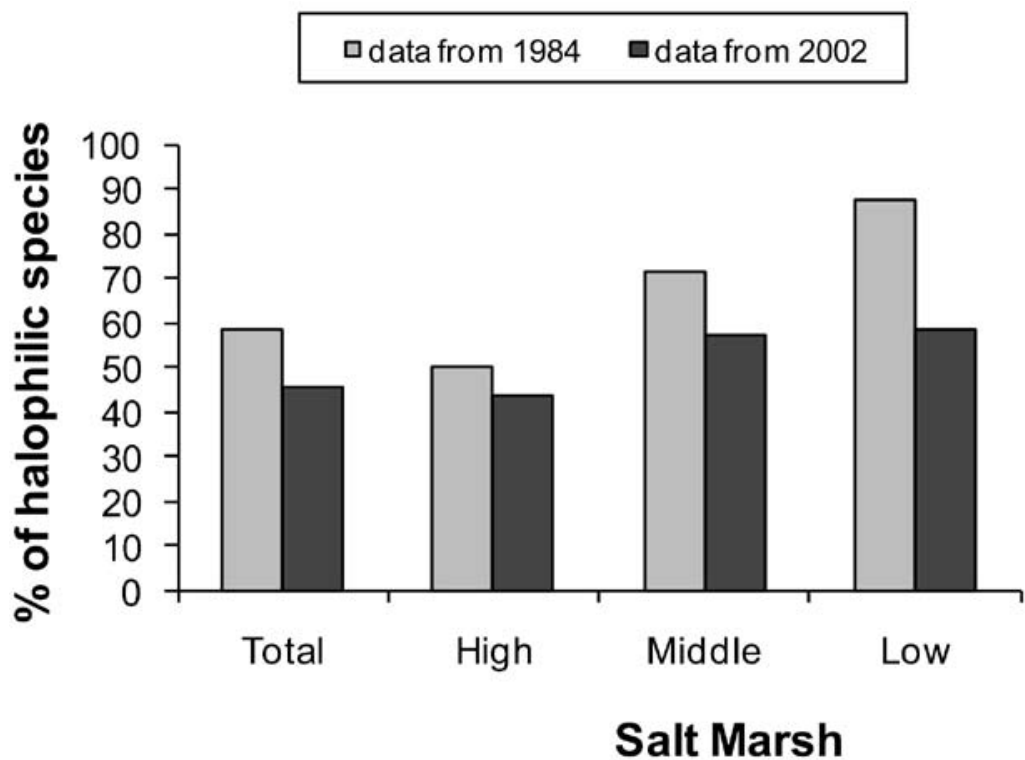

Figure 2. Changes in the percentage of halophilic species in the salt marsh after the invasion by Elymus athericus.

stenotopic species in ground beetle assemblages than in spider assemblages have been recorded in other flooded habitats, such as river floodplains (Rothenbücher \& Schaefer 2006) and riverbanks (Bonn \& Kleinwächter 1999).

Although the sampling effort was quite different between 1983-1984 and 2002, we assume that around 11 records of the 16 new species during the second sampling period can also be due to the invasion by Elymus. In fact, several continental species were discovered after the invasion in relatively high numbers (i.e., more than five individuals), both on the dyke and in the salt marsh. Among them, most species are linked to high contents of organic matter and a more pronounced litter layer (e.g., Agonum muelleri, Bembidion obtusum and the polyphagous Pterostichus versicolor) or are even partly phytophagous (Amara spp. and Harpalus spp.: Dajoz 1988, Ikeda et al. in press). Conversely, halophilic species discovered in 2002 are hardly related to the invasion. Pogonus littoralis and Dicheirotrichus obsoletus could have been misidentified earlier, as these species are very similar to $P$. chalceus and D. gustavii, respectively (Forel \& Leplat 2005, Dhuyvetter et al. 2007). D. obsoletus could also have been missed in 1983-1984 (the sampling stopped in September) as more than $89 \%$ of individuals were caught in October-November during 2002. Tachys scutellaris appears as a new species in 2002, but was present in 1983-1984, but at another station located below the mean sea level (slikke habitat: Fouillet 1986). The 'appearance' of several species, sampled in low numbers in 2002, can be due to differences in sampling effort and/or to random catches.

The synchronic study revealed that almost half of the species (8/19), both continental and halophilic ones, were shared between natural and invaded habitats. Three species, all halophilic, were exclusive to natural habitats. Conversely, six species were 
Table 2. Comparison of total species richness (total S), mean species richness (mean $S$ ) and means abundances (as expressed in number of individuals per day and per meter) of Pogonus chalceus, Dicheirotrichus obsoletus, Bembidion normanum, Dicheirotrichus gustavii and Bembidion minimum between natural $(\mathbf{N})$ and invaded $(\mathbf{I})$ habitats. Means in bold are significantly different $(\mathrm{p}<0.05)$ between habitat types (mean \pm s.e., see text for details in statistics).

\begin{tabular}{l|c|c|c|c|c|c|c|c}
\hline \multirow{3}{*}{ Total S } & $\mathbf{N}$ & $\mathbf{I}$ & $\mathbf{N 1}$ & $\mathbf{I 1}$ & $\mathbf{N 2}$ & $\mathbf{I 2}$ & $\mathbf{N 3}$ & I3 \\
\cline { 2 - 9 } Mean S & $\mathbf{1 1}$ & $\mathbf{1 4}$ & & & & & & \\
& 6.17 & 6.92 & $\mathbf{5 . 5 0}$ & $\mathbf{8 . 7 5}$ & 6.25 & 6.50 & 6.75 & 5.50 \\
& \pm 0.35 & \pm 0.51 & $\mathbf{\pm 0 . 5 0}$ & $\mathbf{\pm 0 . 4 8}$ & \pm 0.63 & \pm 0.65 & \pm 0.63 & \pm 0.65 \\
\hline P. chalceus & 7.66 & 4.75 & 1.11 & 1.68 & 13.50 & 10.76 & $\mathbf{8 . 3 7}$ & $\mathbf{1 . 8 0}$ \\
& \pm 1.90 & \pm 1.91 & \pm 0.32 & \pm 0.24 & \pm 3.35 & \pm 4.63 & $\mathbf{\pm 1 . 5 5}$ & $\mathbf{0 . 7 4}$ \\
\hline D. obsoletus & 1.38 & 1.68 & & & & & & \\
& \pm 0.60 & \pm 0.72 & & & & & & \\
\hline B. normanum & 0.78 & 0.98 & & & & & & \\
& \pm 0.35 & \pm 0.40 & & & & & & \\
\hline D. gustavii & 0.45 & 0.68 & 0.03 & 0.02 & $\mathbf{1 . 1 4}$ & $\mathbf{1 . 9 9}$ & $\mathbf{0 . 1 9}$ & $\mathbf{0 . 0 5}$ \\
& \pm 0.15 & \pm 0.29 & \pm 0.02 & \pm 0.01 & $\mathbf{\pm 0 . 1 5}$ & $\mathbf{\pm 0 . 2 9}$ & $\pm \mathbf{0 . 0 4}$ & $\mathbf{\pm 0 . 0 2}$ \\
\hline B. minimum & $\mathbf{0 . 2 9}$ & $\mathbf{0 . 5 2}$ & & & & & & \\
& $\mathbf{0 . 1 1}$ & $\mathbf{\pm 0 . 1 0}$ & & & & & & \\
\hline
\end{tabular}

exclusive to invaded habitats, among them some of the species that colonized the marsh after the invasion by Elymus athericus (e.g., Bembidion lampros or Pterostichus cupreus). New conditions created by the grass Elymus - mainly an enhanced litter layer and higher plant cover - thus lead to the establishment of several continental species directly or indirectly linked to organic matter or to the litter (as shown by Pétillon et al. 2008).

Although few deleterious impacts of invasion by Elymus athericus on carabids were found, management could be necessary to reduce the effects of invasion and decrease the rate of spread of the invasive plant. Sheep grazing - despite being a good potential method for biological control of invaders (Shea \& Chesson 2002) - is at the moment carried out too intensively in the Mont Saint-Michel bay, leading to a decrease in carabid species richness (Pétillon et al. 2007). A low stocking rate (i.e., between 0.5 and 1.5 sheep $\mathrm{ha}^{-1}$ ) can therefore be recommended, assuming greatest positive effects at intermediate disturbance intensities (for arthropods: e.g., Dennis et al. 2001, Suominen et al. 2003).

Long-term monitoring of population dynamics is thus recommended for halophilic species in invaded, natural and managed habitats. Special attention could be paid to less dominant species, as their small populations could be reduced faster than other, dominant, salt-marsh carabids. This study confirms the high value of carabids as bioindicators (as they present a high percentage of specialist species) and shows the possibility of using long-term surveys for ecological studies, if carefully interpreted.

\section{Acknowledgments}

We thank S. Le Gleut, E. Pétillon, S. Cobbold, G. Dubois and G. Montfort for field assistance, and François Rineau for help in identification. Sébastien Dugravot im- 
proved the English version of this manuscript. This study was supported by the French Ministry of Environment (Programme 'Espèces invasives') and the CNRS Zone Atelier 'La Baie du Mont Saint-Michel et ses bassins versants'.

\section{References}

Adam P (2002) Saltmarshes in a time of change. Environmental Conservation 29: 39-61. doi: $10.1017 /$ S0376892902000048

Bakker JP, Esselink P, Dijkema KS, Duiin WE van, Jong DJ de (2002) Restoration of salt marshes in the Netherlands. Hydrobiologia 478: 29-51. doi: 10.1023/A:1021066311728

Bockelmann AC, Neuhaus R (1999) Competitive exclusion of Elymus athericus from a high-stress habitat in a European saltmarsh. Journal of Ecology 87: 503-513. doi: 10.1046/j.13652745.1999.00368.x

Bonn A, Gaston KJ (2005) Capturing biodiversity: selecting priority areas for conservation using different criteria. Biodiversity and Conservation 14: 1083-1100. doi: 10.1007/ s10531-004-8410-6

Bonn A, Kleinwächter M (1999) Micro-habitat distribution of spider and ground beetle assemblages (Araneae, Carabidae) on frequently inundated river banks of the River Elbe. Zeitschrift für Ökologie und Naturschutz 8: 109-123.

Dajoz R 1988. Le régime alimentaire des Coléoptères Carabidae et son importance dans le fonctionnement des écosystèmes. Cahiers des Naturalistes 43: 61-96.

Dennis P, Young MR, Bentley C (2001) The effects of varied grazing management on epigeal spiders, harvestmen and pseudoscorpions of Nardus stricta grassland in upland Scotland. Agriculture, Ecosystems and Environment 86: 39-57. doi: 10.1016/S0167-8809(00)00263-2

Desender K, Maelfait J-P (1999) Diversity and conservation of terrestrial arthropods in tidal marshes along the River Schelde: a gradient analysis. Biological Conservation 87: 221229. doi: 10.1016/S0006-3207(98)00058-5

Dhuyvetter H, Maelfait J-P, Desender K (2007) Inter- and intraspecific genetic and morphological variation in a sibling pair of carabid species. Saline Systems 3: 4. doi: 10.1186/1746-1448-3-4

Dufrêne M, Legendre P (1997) Species assemblages and indicator species: the need for a flexible asymmetrical approach. Ecological Monographs 67: 345-366.

Esselink P, Zijlstra W, Dijkema KS, Van Diggelen R (2000) The effects of decrease in management on plant-species distribution patterns in a salt-marsh nature reserve in the Wadden Sea. Biological Conservation 91: 61-76. doi: 10.1016/S0006-3207(99)00095-6

Forel J, Leplat J (2005) Faune des carabiques de France - X. Magellanes, Andrésy, 128 pp.

Foster WA, Treherne JE (1976) Insects of marine saltmarshes: problems and adaptations. In: Cheng L (Ed) Marine insects. North-Holland Company, Amsterdam, 5-42.

Fouillet P (1986) Evolutions des peuplements d'Arthropodes des schorres de la baie du Mont Saint-Michel: influence du pâturage ovin et conséquences de son abandon. PhD thesis, Rennes, France: University of Rennes 1.

Goeldner-Gianella L (1999) Réouverture de polders et restauration des marais salés en Angleterre. Géographie des littoraux : la nature et les hommes. Revue de Géographie de Lyon 74: 75-84. 
Georges A (1994) Carabid beetles as indicators of current and historical land form and land use changes in wetlands. International Journal of Ecology and Environmental Sciences 20: 129-147.

Hulbert SH (1984) Pseudoreplication and the design of ecological field experiments. Ecological Monographs 54: 187-211. doi: 10.2307/1942661

Ikeda H, Kubota K, Kagawa A, Sota T (2010) Diverse diet compositions among harpaline beetle species revealed by mixing model analyses of stable isotope ratios. Ecological Entomology 35: 307-316. doi: 10.1111/j.1365-2311.2010.01182.x

Irmler U, Heller K, Meyer H, Reinke H-D (2002) Zonation of ground beetles (Coleoptera: Carabidae) and spiders (Araneida) in salt marshes at the North and the Baltic Sea and the impact of the predicted sea level increase. Biodiversity and Conservation 11 : 1129-1147. Jeannel R (1942) Coléoptères carabiques. Editions Lechevalier, Paris, 600 pp. doi: 10.1023/A:1016018021533

Kamer N, Dormann W, Mossakowski D (2008) Patterns of molecular variability in Carabid beetles mostly from the Baltic Sea coast. In: Pennev L. Erwin T, Assmann T (Eds) Back to the roots and back to the future. Towards a new synthesis amongst taxonomic, ecological and biogeographical approaches in carabidology. XIII European Carabidologists meeting, Blagoevgrad (Bulgaria), August 2007. Pensoft Publishers, Sofia-Moscow, 195-206.

Lefeuvre J-C, Laffaille P, Feunteun E, Bouchard V, Radureau A (2003) Biodiversity in salt marshes: from patrimonial value to ecosystem functioning. The case study of the Mont-Saint Michel bay. Comptes Rendus Biologies 326: 125-131. doi: 10.1016/S1631-0691(03)00049-0

Leport L, Baudry J, Radureau A, Bouchereau A (2006) Sodium, potassium and nitrogenous osmolyte accumulation in relation to the adaptation to salinity of Elytrigia pycnantha, an invasive plant of the Mont Saint-Michel Bay. Cahiers de Biologie Marine 47: 31-37.

Lindroth CH (1992) Ground beetles of Fennoscandia. Intercept, Andover, 814 pp.

Luff ML (1998) Provisional atlas of the ground beetles (Coleoptera, Carabidae) of Britain. Biological Records Centre, Huntington, 194 pp.

Luff ML, Eyre MD, Rushton SP (1992) Classification and prediction of grassland habitats using ground beetles (Coleoptera, Carabidae). Journal of Environmental Management 35: 301-315. doi: 10.1016/S0301-4797(11)80012-5

McGoech M (1998) The selecting, testing and application of terrestrial insects as bioindicators. Biological Reviews 73: 181-201. doi: 10.1017/S000632319700515X

Meijer J (1980) The development of some elements of the arthropod fauna of a new polder. Oecologia 45: 220-235. doi: 10.1007/BF00346463

New TR (1995) An introduction to invertebrate conservation biology. Oxford University Press, New York, 206 pp.

Noss RN (1990) Indicators for monitoring biodiversity: a hierarchical approach. Conservation Biology 4: 355-364. doi: 10.1111/j.1523-1739.1990.tb00309.x

Pétillon J (2005) Evolutions structurales, conservatoires et fonctionnelles de marais salés envahis par le chiendent: études de communautés d'Arthropodes en baie du Mont Saint-Michel. PhD thesis, Rennes, France: University of Rennes 1.

Pétillon J, Georges A, Canard A, Lefeuvre J-C, Bakker JP, Ysnel F (2008) Influence of abiotic factors on spider and ground beetles communities in different salt-marsh systems. Basic and Applied Ecology 9: 743-751. doi: 10.1016/j.baae.2007.08.007 
Pétillon J, Montaigne W, Renault D (2009) Hypoxic coma as a strategy to survive inundation in a salt-marsh inhabiting spider. Biology Letters 5: 442-445. doi: 10.1098/rsbl.2009.0127

Pétillon J, Ysnel F, Canard A, Lefeuvre J-C (2004) Responses of spider communities to a salinity gradient and tidal flooding in a tidal salt marsh (Mont St-Michel Bay, France). Arthropoda selecta 1(suppl.): 235-248.

Pétillon J, Ysnel F, Canard A, Lefeuvre J-C (2005) Impact of an invasive plant (Elymus athericus) on the conservation value of tidal salt marshes in western France and implications for management: responses of spider populations. Biological Conservation 126: 103-117. doi: 10.1016/j.biocon.2005.05.003

Pétillon J, Georges A, Canard A, Ysnel F (2007) Impact of cutting and sheep-grazing on ground-active spiders and ground beetles in some intertidal salt marshes (Western France). Animal Biodiversity and Conservation 30: 201-209.

Rainio J, Niemelä J (2003) Ground beetles (Coleoptera: Carabidae) as bioindicators. Biodiversity and Conservation 12: 487-506. doi: 10.1023/A:1022412617568

Rothenbücher J, Schaefer M (2006) Submersion tolerance in floodplain arthropod communities. Basic and Applied Ecology 7: 398-408. doi: 10.1016/j.baae.2006.05.005

Samways MJ (1993) Insects in biodiversity conservation: some perspectives and directives. Biodiversity and Conservation 2: 258-282. doi: 10.1007/BF00056672

Shea K, Chesson P (2002) Community ecology theory as a framework for biological invasions. Trends in Ecology and Evolution 17: 170-176. doi: 10.1016/S0169-5347(02)02495-3

Sunderland K, Lövei G (1996) The ecology and behaviour of ground beetles. Annual Review of Entomology 41: 231-256.

Sunderland KD, De Snoo GR, Dinter A, Hance T, Helenius J, Jepson P, Kromp B, Samu F, Sotherton NW, Toft S, Ulber B (1995) Density estimation for invertebrate predators in agroecosystems. In: Toft S, Riedel W (Eds) Arthropod natural enemies in arable land, I. Density, spatial heterogeneity and dispersal. Aarhus University Press, Aarhus, 133-162. doi: 10.1146/annurev.en.41.010196.001311

Suominen O, Niemelä J, Martikainen P, Niemelä P, Kojola I (2003) Impact of reindeer grazing on ground-dwelling Carabidae and Curculionidae assemblages in Lapland. Ecography 26: 503-513. doi: 10.1034/j.1600-0587.2003.03445.x

Topping CJ, Sunderland KD (1992) Limitations to the use of pitfall traps in ecological studies exemplified by a study of spiders in a field of winter wheat. Journal of Applied Ecology 29: 485-491. doi: 10.2307/2404516

Trautner J, Geigenmüller K (1987) Illustrated key to the Cicindelidae and Carabidae of Europe. Verlag Josef Margraf, Aichtal, 488 pp.

Turin H (2000) De Nederlandse Loopkevers. KNNV Uitgevij, Utrecht, 666 pp.

Valéry L, Bouchard V, Lefeuvre J-C (2004) Impact of the invasive native species Elymus athericus on carbon pools in a salt marsh. Wetlands 24: 268-276. doi: 10.1672/0277-5212(2004)024[0268:IOTINS]2.0.CO;2

Valéry L, Fritz H, Lefeuvre J-C, Simberloff D (2009) Invasive species can also be native... Trends Ecol Evol 24: 585 